\title{
Improving Photosynthesis Learning with Adventure 3D Games Based on Augmented Reality Experience
}

\author{
$1^{\text {st }}$ Moh. Zikky ${ }^{1}, 2^{\text {nd }}$ Dwi Antini Rohmah Dea ${ }^{1}, 3^{\text {rd }}$ Kholid Fathoni $^{1}, 4^{\text {th }}$ Abdulloh Hamid $^{2}$ \\ \{zikky@pens.ac.id ${ }^{1}$,kholid@pens.ac.id ${ }^{1}$,doelhamid@uinsby.ac.id² \\ Politeknik Elektronika Negeri Surabaya ${ }^{1}$, Universitas Islam Negeri Sunan Ampel Surabaya, \\ Indonesia $^{2}$
}

\begin{abstract}
D Games based on Augmented Reality is a new innovation in conventional learning process to describe photosynthesis process of Nature Science subjects. Utilization of learning media with Augmented Reality is due to the rapid growth of technology in education. 3D games based on Augmented Reality on the mobile is expected to facilitate teachers in providing photosynthesis material to students. This game will explain how the plant process makes its own food through the help of sunlight. Students will immediately play, learn and feel the process of how photosynthesis works. The learning process by utilize mobile games will make students become more active in the learning process.
\end{abstract}

Keywords: Augmented Reality, Photosynthesis, Mobile Game

\section{Introduction}

The world of education, especially in Indonesia is very concerned about the quality of education. The quality of education itself is influenced by many factors, students, school managers (principals, employees and school committees or committee), environment (parents, community, school), learning quality, and curriculum. Thus, one important factor to achieve the goal of education is the process of learning. The learning process certainly can't be separated from the role of media that being used to teach the student. Especially for one lesson in elementary school that utilizes the development of Science and Technology (Science and Technology) IPA, these subjects require interactive learning media with visual aids as a tool to educate and facilitate in achieving the competence of learning [1].

Based on the Minister of Education and Culture of the Republic of Indonesia, Educational Field in the concept and implementation of 2013 curriculum presented the result of PISA (Program for International Student Assessment) reflection science in 2007 and 2011 stated that Indonesian students are only able to reach intermediate level, therefore the Indonesian government prepare some efforts to restore the state of the PISA science results. [2] One of the efforts of the Indonesian government in the science of providing visual aids to be more optimal in directing students to a form of understanding, the role of teachers as well as facilitators who designed the lesson to be better understood by students.

That is called photosynthesis subject in school. This subject explains the process by which green plants use light energy to make their own food, that is what is called photosynthesis. [3] However, the photosynthetic subject described in schools generally uses lecture or storytelling 
methods. So that children can only listen, see pictures and imagine it without any practice of physical equipment about the process of photosynthesis that results in boredom for students.

Therefore, to overcome boredom and assist students in understanding the subject matter of science especially photosynthesis subject, we make the Design of Photosynthesis Games for Students of Class V SD which is packed with Adventure 3D Game concept and Augmented Reality based. The reason we choose games because some groups such as educators, businessmen and jobs like the military use video games for information and develop skills. Video games can develop and very effective media at providing variations in school subjects such as algebra, geometry, and biology. The game is an effective medium for teaching because it contains effective instructional principles and instructional techniques used in reinforcement at difficult levels.

\section{Use of Augmented Reality}

Augmented Reality (AR) is a variation of the Virtual Environment (VE) or so-called Virtual Reality. Augmented Reality is defined as a technology that can combine the real world with the virtual world, interactive in real time, and 3D animated. Augmented Reality has been applied into two versions, using markers or marker less.

Augmented reality that is using marker is a combination of the real world and the virtual world. We can see an interactive virtual world from mobile phone. As in children's food products that use a lot of branding products by utilizing this augmented reality technology. The branding includes AR card, education, or interactive game that attract children to play it. The camera captures an image in the environment, then detects the marker and deducts location and camera orientation, then the virtual image appears above the marker grid and is displayed on the monitor screen.

Augmented Reality technology is a very famous topic because users can interact with the real world. Augmented Reality can be applied in some experiences such as health visualization, maintenance and repair, annotation, robot path planning, entertainment, and military aircraft navigation and targeting. [4]

This lesson is presented by creating a marker of a book that has content on photosynthesis. The photosynthesis book will be the marker to show the object and games. This marker book is compiled based on the material reference on the textbook of Natural Science of Elementary School Children at school. This book contains all kinds of photosynthetic materials, photosynthetic simulation videos, photosynthesis mini-games and some quizzes. The marker used in books designed on CorelDraw software.

Markers that have a lot of shapes and the more complicated the picture then it can be regarded as a good marker because it could be worth five stars, a sign that the marker is good to be a marker.

\section{Related Works}

There are several works that related to our works. Here we reviewed the work and gave some comparison with our work. 


\subsection{Three-dimensional Visualization of Plant Photosynthesis Process using Particle System}

This research designs an interactive multimedia learning system in the form of visualization of the photosynthesis process which will be included in an interactive learning app for 5th-grade elementary school. This learning media contains information about the photosynthesis process that comes with a 3D animated video created with the help of existing effects in 3DMax software to produce rain animation in photosynthesis process and material about the role of green plants for other living creatures [5].

\subsection{D Game-Like Virtual Environment for chemistry Learning}

This research was conducted by Eman Ahmad who showed the concept of implementation and experience in the 3D educational game for interactive chemistry learning. This educational game is real-time and multiuser with technical "learning by playing" which will become a powerful learning strategy in learning chemistry. In this study players tend to learn by playing the virtual world, easier to understand with $3 \mathrm{D}$, a nice $3 \mathrm{D}$ effect makes the player involved playing and overall fun [6].

\subsection{Implementation of Augmented Reality in the Development of Photosynthetic Material Interactive Learning Media for Students in Grade 5 of SD Budi Luhur Pondok Aren}

This research produces Plant AR products that focus on visualization of the photosynthesis process, in addition there is other supporting content in applications that include the introduction of green plants, about photosynthesis, the benefits of photosynthesis for living things and the question of evaluation.

Students tested the Plant AR interface and against Augmented Reality. The results of questionnaires to 60 respondents consisting of 5th-grade elementary school concluded that the application is in accordance with the eight rules of interface design so that users feel the increased interest in learning [7]. In $83 \%$ of students stated that 3D animation design on Plant AR learning media is easy to use and attract interest in learning.

\section{Basic Interactive Game}

Augmented Reality Photosynthesis application will be presented in the form of simple games such as click and choose the required options, directing the movement to the right and left to achieve the mission of the game. In this app there are some features like mini-game, simulation video, and quiz. This in-app game explains each process of photosynthesis for learning in school. This photosynthesis game is 3D-based and made in Unity software. 


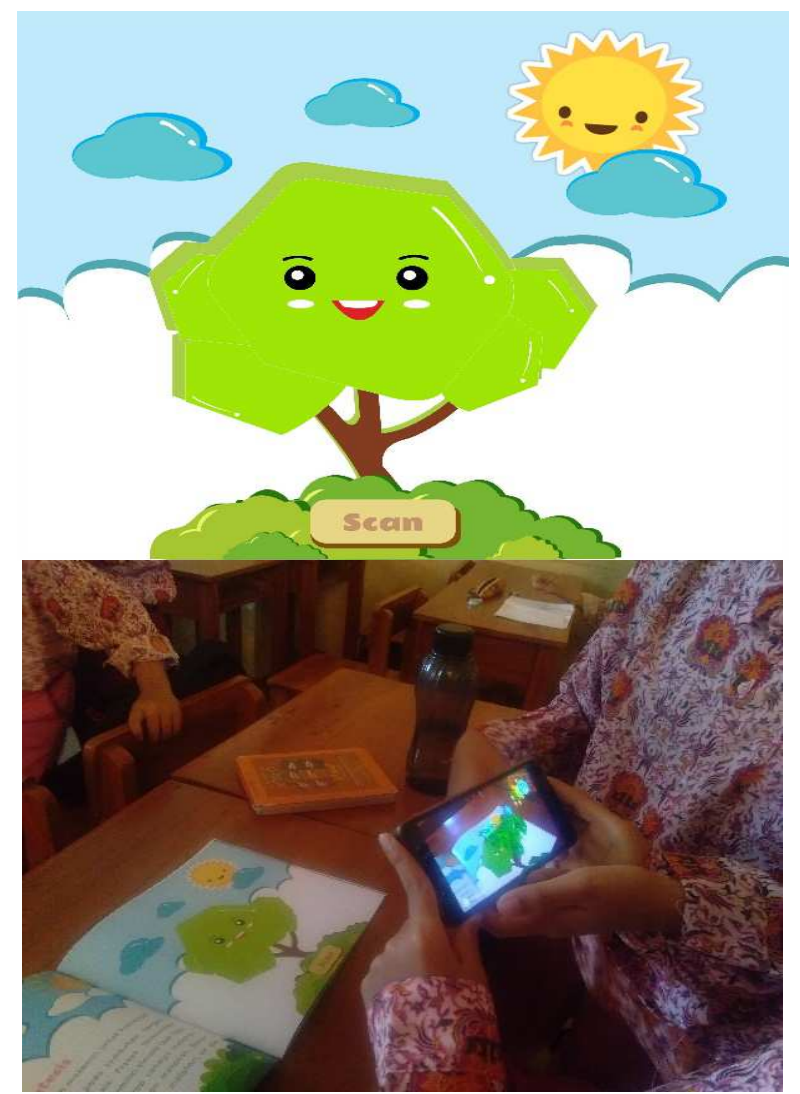

(a)

Figure 1. The photosynthetic chapter (a) is selected and scanned the marker so that it displays a 3D photosynthesis object consisting of trees, sunlight, carbon dioxide and water.

The photosynthetic chapter as seen above illustrates the photosynthesis materials with sounds that explain the process of photosynthesis.

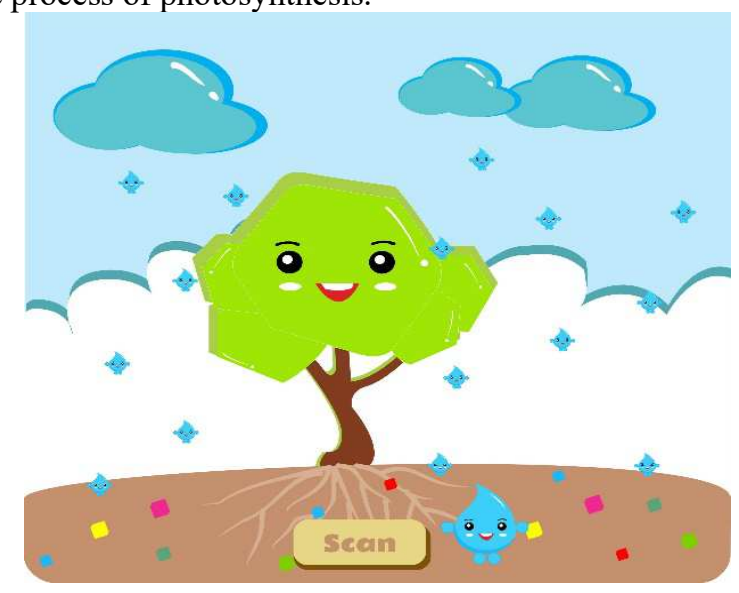




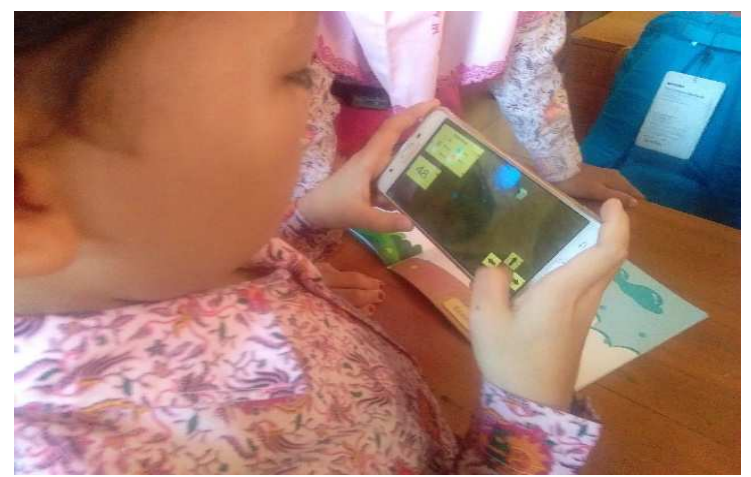

(b)

Figure 2. The chapter Level 1 Game Photosynthesis (b) is selected and scanned the marker so that it displays a photosynthetic game that directs the character of the water to take minerals in the soil

This photosynthesis chapter explains how this water character picks up some of the minerals in the soil. Minerals consist of Iron, Magnesium, Calcium, Silicon. The character of water is required to take all the minerals in the soil to continue on the next process.

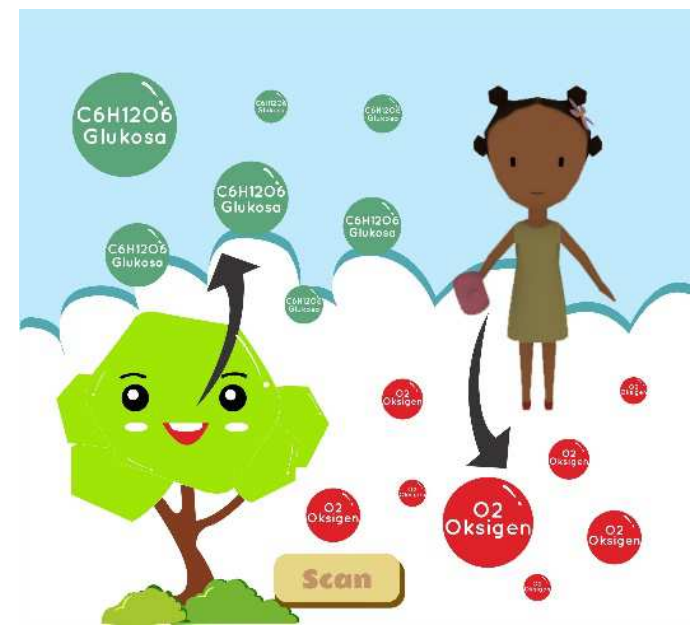

(c)

Figure 3. The book on chapter Level five Photosynthesis (c) is selected and scanned the marker so that it displays photosynthesis games in the distribution of photosynthesis results.

In this chapter explains the distribution of photosynthesis results. Photosynthesis results are Oxygen and Glucose (carbohydrates). Oxygen will be inhaled and a need for living things like humans and animals. Glucose (carbohydrates) will return to the plant body as a food reserve.

\section{Research Question}


In this study, it aims to obtain information about whether photosynthesis learning with presentation using Augmented Reality technology is an appropriate medium for conveying learning to children.

\subsection{Methods}

The method used in this research that there are two, using quantitative and qualitative. Quantitative research is based on the provisions made in the questionnaire in obtaining data of interest information from students to retry the application, and the teacher needs information on the progress of the students about the material that has been tested in using the application. Additionally, quantitative is usually obtained from pretest and post test work on paper sheets such as exams using pencil on paper. In order to pre-test and post-test, it allows us to assess that the level of understanding of children before and after learning using the application can be seen.

While in qualitative research conducted aims to find out about the ease of the application for the development again. Qualitative is done directly to students and interviews to classroom teachers to get information about responses and suggestions for application development.

\subsection{Respondent}

There are two respondents in this research, namely:

- Student

Elementary School students are 11 people who the author took for questionnaire data. Elementary School students have a lot to understand about technology and games because the age of students now has entered in the era of technology.

- Teacher

The teacher was a homeroom teacher from the fifth grade and the author got criticism and advice from the related teacher for application development.

\subsection{Scenario}

Scenarios in the data retrieval are done first by using the response of the pre-test that contains the related material to be discussed about photosynthesis and the student has never at all received this material, even just glance knowing.

The student respondents will use our application in the process of photosynthesis and then the authors will perform an analysis of before students use the application until students use the application.

After the application test, it will be held post test in order to measure the level of understanding of children about photosynthesis material that students used. Posttest is used as the end result of the students in understanding the material photosynthesis.

Respondent the teacher is done by interviewing and trying the writer application the same as done by the students.

\subsection{Result and Discussion}

From the results of research that can be taken conclusion, students who use the application more interested to learn about photosynthesis. According to them this app is useful for their learning. They can explore and get to know more closely using Augmented Reality technology.

User of Augmented Reality technology has a positive impact on student learning progress. This technology is expected to be a child's learning companion so that children do not learn on objects that are monotonous like a regular textbook. With the provision of several mini-games 
in the application of Augmented Reality Photosynthesis is helping children while learning to understand the material taught.

Interface design obtained from student respondents MI Muhammadiyah 5 Surabaya:

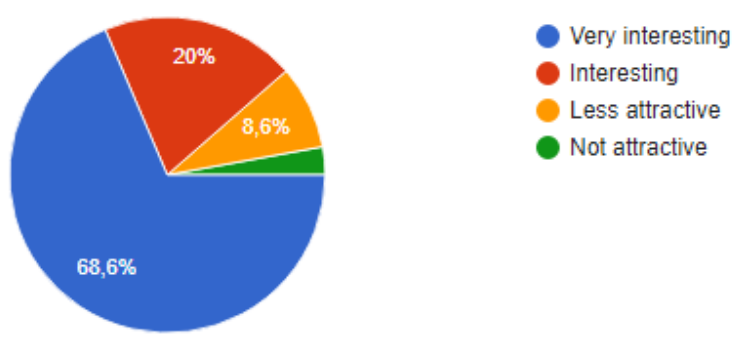

Figure 4. User Interface: "How to display the Augmented Reality Photosynthesis application"

From the percentage above, it can be seen that this application has a very attractive interface design. Votes with $68.6 \%$ of respondents said very interesting, and $20 \%$ of respondents said interesting, and $8.6 \%$ said less interesting.

The results of calculating the ease of use of the application:
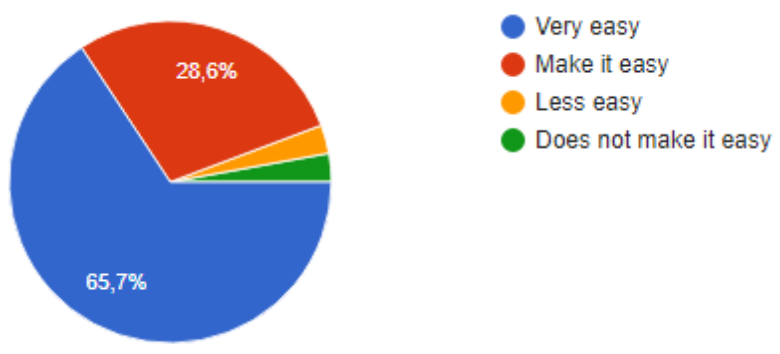

Figure 5. Ease to use the application "How is the ease of application use?"

From the above percentage, it can be seen that this application is very easy. Results based on the convenience of this application equal to the previous percentage.

The results of testing in the application's usefulness:

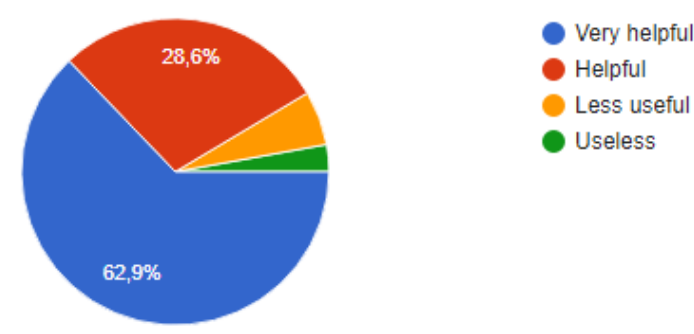

Figure 6. Usefulness "Whether the application is useful for your learning process?" 
From the percentage above, it can be seen that this application has very useful results. Votes with $45.5 \%$ of respondents said very useful, and $54.5 \%$ of respondents stated useful.

Acknowledgements. This paper in conjuction with the 3rd International Conference on Indonesian Economy \& Development (ICIED 2018)

\section{References}

[1] Widiyatmoko A, S.D. Pamelasari. Pembelajaran Berbasis Proyek Untuk Mengembangkan Alat Peraga IPA dengan Memanfaatkan Bahan Bekas Pakai. Semarang. Universitas Negeri Semarang 2012.

[2] Paparan Wakil Menteri Pendidikan dan Kebudayaan R.I Bidang Pendidikan tentang Konsep dan Implementasi Kurikulum 2013.

[3] BBC, "BBC Bitesize - National 4 - Biology - Cell Biology - Photosynthesis and respiration." In BBC Bitesize, 2017. [Online]. Available:

http://www.bbc.co.uk/education/guides/zjpk7ty/revision. Accessed: July. 11, 2017.I. S. Jacobs and C. P. Bean, "Fine particles, thin films and exchange anisotropy," in Magnetism, vol. III, G. T. Rado and H. Suhl, Eds. New York: Academic, pp. 271-350 1963.

[4] Azuma, Ronald T. A Survey of Augmented Reality in Presence: Teleoperators and Virtual Environment 6, 4 (August 1997), 355-385. Malibu.R. Nicole, "Title of paper with only first word capitalized," J. Name Stand. Abbrev., in press 1997.

[5] Kurniawan Ahmad Syaugy. Visualisasi Tiga Dimensi Proses Fotosintesis Tumbuhan Menggunakan Particle System (Efek Partikel) (Studi kasus SDN Kebayoran Lama Selatan 13 Pagi. Jakarta. Universitas Syarif Hidayatullah 2011.

[6] Shudayfat Eman Ahmad, dkk. 3D Game-Like Virtual Environment For Chemistry Learning. Romania. University POLITEHNICA of Bucharest 2015.

[7] Nurochmah Dewi, dkk. Implementasi Augmented Reality Pada Pengembangan media Pembelajaran Interaktif Materi Fotosintesis Untuk Siswa Kelas 5 SD Budi Luhur Pondok Aren. Jakarta. Universitas Islam Negeri Syarif Hidayatullah 2014. 